IUGJEPS

Vol 29, No 3, 2021, pp 874 - 887

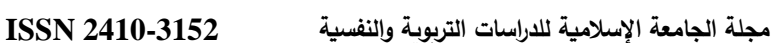

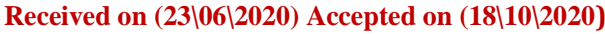

\section{A Meta-Analysis of Reading Research around the World: Towards a Set of Guiding Principles for EFL Reading Instruction}

\author{
Main Researcher: \\ Second Researcher: \\ Third Researcher \\ 1 University Name \& City: \\ 2,3 University Name \& City:
}

* Corresponding author:

E-mail address: alzoubitahani5@gmail.com
Tahani Khalid Al-Zou'bi

Prof. Ruba Fahmi Bataineh

Dr. Mohammad Ali Al-Khawaldeh

\begin{tabular}{|c|}
\hline $\begin{array}{c}\text { Department of Curriculum and Methods of Teaching, Yarmouk } \\
\text { University }\end{array}$ \\
\hline Yarmouk University
\end{tabular}

https://doi.org/10.33976/IUGJEPS.29.3/2021/39

\title{
A Meta-Analysis of Reading Research around the World: Towards a Set of Guiding Principles for EFL Reading Instruction
}

\section{Abstract:}

This study attempted to shed light on the reading research conducted over the last twenty years for the purpose of reflecting on the most and least addressed aspects of reading in the research. This study is also hoped to constitute a resource for scholars about the latest initiatives in the reading research in general and in EFL reading in particular. In order to answer the research aims, a metaanalysis of 45 articles was conducted. Despite the fact that the methodology adopted for this study was thematic and qualitative, frequency counts were made. A corpus of 45 international articles titles, which met the selection criteria within the overall database of five leading journals, was collected. A seven-step procedure was followed to sort and analyze the data. The findings showed that there were six major themes, which were ranked in terms of their frequency of distribution into reading comprehension, reading strategies, reading ability, reading literacy, reading speed, and reading skills. In light of the findings, the researchers attempted to highlight the areas of focus and to put forth guiding principles for reading instruction (e.g., strategy-based instruction is essential in teaching reading; technology-based instruction is more a must than an alternative).

Keywords: guiding principles, meta-analysis, reading research.

تحليل تجميعي لبحوث القراءة حول العالم: نحو مجموعة من المبادئ الموجهة لتدريس القراءة باللغة الإنجليزية لغة أجنبية في الأردن

الملخص:

هدفت الدراسة إلى تعرف الجهود المبذولة حول القراءة في الدراسات العالمية والمحلية لتكون مصدرا للباحثين فيما يخص القراءة عامة،

والقراءة باللغة الإنجليزية لغة أجنبية، والخروج بمجموعة من المبادئ الموجهة لتدريس القراءة في الأردن. ولإجابة عن أهداف الدراسة، اُختير التحليل التجميعي لبحوث القراءة العالمية الذي يركز بدوره على التحليل النوعي بالرغم من استخدام التكرارات. وقد جرى دراسة 45 دراسة من مجلات رائدة بتدريس اللغة الانجليزية أختيرت حسب معايير حددها الباحثون سلفا. واشتملت الإجراءات على سبع خطوات لتصنيف النتائج وتحليلها، ولوحظ وجود ستة مجالات أساسية يمكن أن تصنف الدراسات ضمنها. وقد وُّّعت هذه المجالات بحسب نسبتها إلى ما يلي: فهم المقروء،

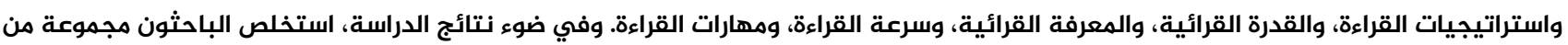

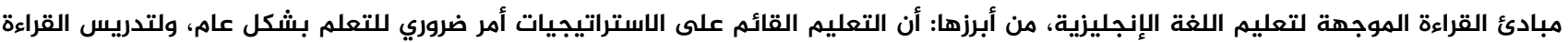
بشكل خاص، وضرورة تفعيل التكنولوجيا بشكل واقعي داخل الغرفة الصفية. 


\section{Research Body:}

Reading is one of the basic skills that students learn in both their first and any additional languages. Early readers focus on code breaking as their reading skills evolve from one level to another (Mckay, 2006). Reading is a receptive skill, but readers are actively involved in the task through complex cognitive processes that work together to achieve successful communication (Mazzante \& Spangler, 2015). Reading also distinguishes between literate and illiterate people and forms the basis for learning other subject matters (Hedgcock \& Ferris, 2009), as it increases the learner's language input and, in turn, fosters his/her vocabulary learning and cultural awareness (Mazzante \& Spangler, 2015).

Reading is defined as a complex linguistic, social, and cognitive process involving the reader, writer, text, context, and purpose (Eagleton \& Dobler, 2007; Hedgcock \& Ferris, 2009). It involves an elaborate interaction of three factors (viz., cognitive processes, reader strategies, and the information in a certain text) as a reader reconstructs the message from a written text to meet his/her schemata and expectations (e.g., Wolf, 2007) through the use of several sub-skills (e.g., decoding, prediction, skimming, scanning).

Reading is a complex skill that entails different variables, and having proficient readers is important at all stages both in Jordan and around the globe (Al-Damiree \& Bataineh, 2016). Some of the major topics to be discussed are reading literacy, reader characteristics, instructional design, extensive reading, literary instruction in EFL reading, and reading assessment (Hedgcock \& Ferris, 2009).

Reading instruction is a complicated issue with a host of variables that may affect its success. Among these factors are the age of the learner, his/her proficiency level, his/her cognitive processes, the relationship between the first and target languages, motivation, the teacher, the curriculum, the instructional context, and available resources (Grabe, 2004).

Three reading models are at play to frame one's understanding of the reading process. The top-down processing model focuses on activities which construct meaning rather than on mastering bottom-up skills (e.g., recognize linguistic cues (letters, morphemes, words, grammatical cues, discourse markers), as students generate meaning by making use of background knowledge, making predictions, and searching the text to confirm or reject their own predictions. The bottomup model emphasizes part-to-whole processing of the text with relatively little emphasis on the effect of the reader's world knowledge, contextual information, and other higher-order strategies. The interactive model allows the reader to alternate between the two models through a systematic pairing in which he/she can successfully activate multiple knowledge sources such as orthography, vocabulary, and schemata (Brown, 2001; Hedgcock \& Ferris, 2009).

Recent explosions of knowledge have reflected on the teaching profession and, thus, it has become vital to conduct meta-analyses to identify the areas of strength and weakness in research, which may help to bridge the gap between research and actual classroom practices.

In order to pursue the goals of language teaching, Omaggio (2001) claims that the best way is to put forth principles to plan and organize instruction instead of searching for an approach or a method. Consequently, she used the concept of proficiency as defined in the Proficiency Guidelines 
of the American Council on the Teaching of Foreign Languages (ACTFL), and recommended other practitioners to find principles that can best suit their own context.

Operational principles play a significant role for guiding and planning foreign literacy instruction (Hedgcock \& Ferris, 2009), which should not be prescribed as a universal curriculum but rather as practical guidelines for designing and implementing foreign language instruction (e.g., "teachers should look carefully and analytically at textual features as they select and prepare them for classroom reading instruction" and "give students ample opportunity to reflect on, react to, and critically analyze the works they have read" (2009:106; 274).

Principles are so crucial in teaching a language, as the choices of teachers in the classroom result from a plethora of underlying language teaching principles (Brown, 2001). Brown posits that enlightened teaching may be achieved by internalizing the connection between the teacher's classroom practices and the principles derived from research. However, these principles should be flexible enough to cope with the constantly growing knowledge (Omaggio, 2001).

Brown (2001) divides teaching principles into three categories: cognitive principles involve automaticity, meaningful learning, the anticipation of reward, the intrinsic motivation, and the strategic investment; affective principles comprise the language ego, self-confidence, risk-taking, and the language-culture connection, and linguistic principles involve the effect of the native language, interlanguage, and communicative competence.

Grabe (2004) conducted a review of previous research and proposed ten guiding principles for teaching reading, as effective reading instruction can be improved by utilizing both the knowledge of practitioners and the findings of research. Of these principles are "emphasize vocabulary learning and create a vocabulary-rich environment, activate background knowledge in appropriate ways, and ensure language knowledge and general comprehension skills" (Grabe, 2004: 46).

The UNESCO International Bureau of Education (2016) published a booklet of the most significant and yet flexible guiding principles for learning in the twenty-first century to bridge the gaps between classroom practices, educational theory and research. Ten aspects of learning under the following four categories were put forth: (1) major areas of knowledge including information literacy, concept focused learning and science, technology, engineering and mathematics (STEM) learning, (2) competences (e.g., critical thinking and creativity, (3) attitudes including academic honesty, health, and mindfulness and service learning, and (4) the broad approaches to learning (e.g., learning support, assessment).

The Bureau based its guiding principles on the relevant academic research and the experiences of teachers. A set of implications for educators regarding each guiding principle was set forth. For example, the guiding principle relating to academic honesty states that "understanding and promoting values of academic honesty enables students to conduct independent research with confidence and integrity" (2016:8) while that relating to critical thinking aims "to nurture inquisitiveness, to model skeptical thought, and to encourage international-mindedness" (2016:14) for students to be autonomous, independent, and open-minded individuals.

Gersten, Baker and Marks (1998) proposed ten guiding principles to assist teachers and specialists to provide services to learners suffering from difficulties, especially those ESL learners in kindergarten to the eighth grade. In preparing their guiding principles, scholars relied on two 
sources: the research on effective instructional practices and a series of focus groups of practicing teachers.

Jinxiu and Zhengping (2016) discussed the importance of preparing a system of guiding principles in designing flexible English reading activities to help Chinese students form good reading habits and to develop their reading: contextualized reading instruction, promoting good reading habits, cultural penetration in reading texts, and integration of the four skills and other English aspects in teaching reading.

Liu and Ning (2017) analyzed the guiding principles of English teaching reform in China in the higher vocational colleges. They reported that the principles in the document are characterized by modularization, individualization, collaboration and hypertextualization. They further recommended keeping up with the latest international trends of teaching English through other studies and utilizing the latest information technology in education.

To conclude, guiding principles are vital in reading instruction. They are the combination of both the knowledge that the teachers have already had along with their real practices in the classroom. These principles can be used in guiding learning, teaching, or assessment.

Teaching should adapt with the new advances around the world and with the technological revolution that the students experience; therefore, guiding principles should lead to a sustainable development in education. That was part of the driving force behind the current study, as the researchers aim to set guiding principles for the Jordanian EFL context.

\section{Problem of the Study}

Despite the many endeavors to improve the quality of EFL instruction in general and reading instruction in particular, EFL students at all levels are reported to suffer from difficulties in reading and reading comprehension (Al-Makhzoumi, 1986; Bataineh \& Al-Barakat, 2005, 2009, 2011; Bataineh \& Al-Shorman, 2005, Bataineh \& Alqatanani, 2011; AlKhawaldeh, 2012; Smadi \& Alshra'ah, 2015; Al-Damiree \& Bataineh, 2016, Bataineh \& Al-Kofeiri, 2018). Although many researchers examined reading difficulties for EFL students (Bataineh \& Barakat, 2005; Hussien, 2012; Al-Jamal, Hawamleh, \& Al-Jamal, 2013; Qrqez \& Ab Rashid, 2017), further research is needed to identify the potential obstacles that face EFL reading.

\section{Purposes of the Study}

This study attempted to shed light on the efforts of scholars during the last twenty years in regard to the reading research. These efforts should be effectively reflected on day-to-day reading instruction. In other words, academic research should be successfully applied in teaching generally and in reading instruction specifically. A meta-analysis of relevant research can offer a resource of different effective experiences to foster students' reading achievement. More specifically, this metaanalysis of reading research aims to derive a set of guiding principles to help teachers improve their instruction and, by extension, their students' reading.

\section{Question of the Study}

The study attempted to find an answer to the question, what has been the major focus of international research on reading since 2000 ?

\section{Significance of the Study}

This study is hoped to constitute a resource for scholars about the latest initiatives in reading instruction in general and EFL reading instruction in particular since there is a plethora of reading 
research to be analyzed and sorted in a way that offers to scholars the areas that require more research. It is also hoped to stimulate meaningful reflection and utilization of the most applicable results of reading research to remedy students' difficulties. The ensuing set of principles is also hoped to contribute to EFL reading instruction, as it would serve as essential guiding principles for quality teaching and learning.

\section{Limitations of the Study}

The generalizability of the findings of this study may be limited to the following factors:

1- The study was limited to a selection of reading research published between 2000 and 2019.

2- The study was limited to research on reading English as a foreign language.

3- The study was limited to research drawn from five leading journals (viz., the Journal of English Language Teaching, International Journal of Instruction, Advances in Language and Literary Studies, International Education Studies, and Journal of Education and Practice).

4- The study was limited only to experimental and quasi-experimental reading research.

\section{Design of the Study}

The researchers adopted the qualitative research design which fits the nature of the current study (despite the use of frequency count). The data for this study were collected from the Education Resources Information Center (ERIC), and Google Scholar. A corpus of 220 articles on EFL reading was identified and analyzed.

\section{Procedures of the Study}

In order to achieve the purposes of the study, the researchers followed these procedures:

1. The researchers reviewed the related literature to establish theoretical as well as practical background of the study.

2. The researchers firstly developed the inclusion criteria to determine which articles were selected for the review. On the basis of the inclusion criteria, the review process covered all the studies on reading from 2000 to 2019.

3. The selected articles were categorized according to their main topics. For instance, reading and the learning contexts, reading strategies and reading evaluation.

4. The frequency of each heading was considered in order to answer the research question which is related to the main focus of scholars in some of the foreign countries.

5. The articles that had evidence of an effective achievement on reading or on any of the reading aspects or skills were thoroughly analyzed.

6. The results of the meta-analysis were presented in regard to the main themes they present.

7. The researchers suggested a set of guiding principles for teaching reading.

\section{Sample of the study}

The sample of the study consisted of articles published in a select group of peer-reviewed journals. The journals and number articles analyzed are as follows: English Language Teaching (140 articles), Advances in Language and Literary Studies (42 articles), International Education Studies (12 results), Journal of Education and Practice (9 articles), and International Journal of Instruction (17 articles).

Forty-five articles were selected per the following criteria: 
1. The research falls within reading English as a foreign language.

2. The research is conducted in countries in which English is a foreign (rather than a second language).

3. The research is published between 2000 and 2019 .

\section{Data Coding}

In order to determine if the articles met the criteria of inclusion in the current meta-analysis, and to compare the different studies included, a coding form for comparison was designed and checked for validity and reliability.

The data were coded into two sections: (1) a summary of information for each study was coded under certain categories (viz., title of the article in which reading is an independent variable, the first author's name, the design of the study under analysis, the dependent and independent variable(s), the population and/or sample, year and duration of implementation, geographical location, the instrument (s), and the major focus of the research), and (2) the themes were identified in terms of the variables of the selected research.

\section{Inclusion Criteria}

The criteria that were set for the inclusion of articles were as follows:

1. It must constitute experimental or quasi-experimental research.

2. It must be published during the period 2000-2019.

3 . It must include the term reading as a keyword in its title.

4. It must deal with reading and/or its aspects (e.g., reading comprehension, fluency) as an independent variable.

5. It must not be targeted purposefully to learners who face severe reading difficulties such as dyslexia.

\section{Results of the Study}

The total number of articles that were identified from the five selected journals was 220 . The number was reduced after applying the inclusion and exclusion criteria to 45 articles, as shown in Table 1.

Table 1: Frequencies of international research in the selected journals

\begin{tabular}{lcc}
\hline \multirow{2}{*}{ Journal Title } & Frequency & \\
\cline { 2 - 3 } & $\begin{array}{l}\text { Initial } \\
\text { Search }\end{array}$ & In/Exclusion criteria \\
\hline English Language Teaching Journal & 140 & 29 \\
Advances in Language and Literacy Studies & 42 & 12 \\
International Journal of Instruction & 17 & 1 \\
International Education Studies & 12 & 1 \\
Journal of Education and Practise & 9 & 2 \\
$\quad$ Total & 220 & 45 \\
\hline
\end{tabular}

The analysis identified some recurring themes under which the EFL reading research was conducted. The reviewed research was found to focus on several themes which were further classified into the six themes of reading comprehension, reading strategies, reading literacy, reading as a general skill, and reading speed, as shown in Table 2. 
Table 2: Ranking of the themes according to the independent variable

\begin{tabular}{|c|l|c|c|}
\hline No. & Focus/Theme & Number of articles & \% \\
\hline 1 & Reading comprehension & 34 & 75.58 \\
\hline 2 & Reading strategies & 4 & 8.88 \\
\hline 3 & Reading ability & 3 & 6.66 \\
\hline 4 & Reading literacy & 2 & 4.44 \\
\hline 5 & Reading speed & 1 & 2.22 \\
\hline 6 & Reading skill & 1 & 2.22 \\
\hline \multicolumn{2}{|l|}{ Total number of articles } & 45 & 100 \\
\hline
\end{tabular}

The reviewed research was further divided according to its respective treatment. Thirteen themes were identified and ranked according to their frequencies, as shown in Table 3.

Table 3: Frequencies of articles by treatment

\begin{tabular}{llcc}
\hline No. & Treatment & Frequency & \% \\
\hline 1 & Reading strategies and strategy training & 13 & 28.8 \\
2 & Type of instruction & 7 & 15.5 \\
3 & Technology & 6 & 13.9 \\
4 & Reading activities & 4 & 8.8 \\
5 & Assessment & 3 & 6.6 \\
6 & Extensive reading & 3 & 6.6 \\
7 & Type of genre & 2 & 4.4 \\
8 & Vocabulary and gloss type & 2 & 4.4 \\
9 & Types of learning & 1 & 2.2 \\
10 & Integrating reading with other skills & 1 & 2.2 \\
11 & Gender and school location & 1 & 2.2 \\
12 & Mode of reading & 1 & 2.2 \\
13 & Vision span & 1 & 2.2 \\
& & 45 & 100 \\
\hline
\end{tabular}

Table 3 shows that the top themes are reading strategies and training (about 29 percent), types of instruction (about 16 percent), technology (about 14 percent).

\section{Discussion of the results}

The current research examined the major focus of the international reading research since 2000. After examining the themes gleaned from the analysis, reading comprehension was the most recurring focus. Reading strategies, reading ability, reading literacy, reading speed, and reading skills were ranked. The results of the study were consistent with what Hedgcock and Ferris (2009) argued about the major factors that affect reading. They argued that reading literacy, text, reader, instructional design, the reading lesson, extensive reading, utilizing literary text in EFL reading instruction, the significance of vocabulary in teaching/learning a foreign language, and reading assessment are all the key factors, with reading comprehension as the optimal goal of reading.

Consequently, reading comprehension should be always emphasized as the ultimate goal of reading instruction. Jordanian students, like many other EFL learners around the world, still suffer problems with comprehending texts. Reading strategies are essential for sustainable development and can be used in real life after school. 
Critical reading is also essential skill, as literacy is a must in this day and age. The majority of disciplines are taught and researched in English language which is the lingua franca of the world. Reading speed is also a significant commodity, as students are required to do tasks or prepare for time-bound tests which necessitate that they read fluently and at speed.

As for the types of treatment, the most common was found to be reading strategies and strategy training, as strategy-based instruction has recently become a global requirement. Type of instruction, which has been a controversial topic since the advent of method-based instruction (e.g., the Direct Method, Audiolingual method) and the subsequent eclectic approach which encourages teachers to opt for optimal modes of instruction to suit the learner needs and abilities (Brown, 2001).

Technology integration into teaching has also had a share in the reviewed research, even though some were as simple as email or WhatsApp. Computer-based programs, electronic mind maps, and blended learning were all used in the reviewed research.

Reading activities were categorized into pre-reading activities (e.g., prior knowledge questions, writing, or timed reading activities) to brainstorm the students' prior knowledge and prepare them for the reading text. Using alternative or dynamic assessment to gauge student progress and encourage them to assess their own progress can positively affect student reading achievement.

Opting for extensive reading to encourage students to read much to improve their reading ability entails that teachers select appropriate reading materials for the students' age and ability. The type of genre is another catalyst, as learners need to encounter various reading genre to be able to read them in- and outside the classrooms.

Students should be made responsible for their own learning, which is fostered by cooperative, learner-centered environments in which the skills are integrated. Integrating reading and writing potentially facilitates reading comprehension, especially if conducive learning environments are achieved.

The eleventh theme pertains to the mode of learning reading, as the reviewed research suggests that silent reading significantly affects students' reading achievement where as the twelfth theme is the vision span which differs from one learner to the other. Students should be trained to reinforce their vision span to increase their reading speed and fluency.

To conclude, the themes discussed above are among the major factors that may affect learning a language in general and learning to read in particular. These factors were also signaled as important in previous research (Brown, 2001; Hedgcock \& Ferris, 2009; Omaggio, 2001).

\section{Guiding Principles}

Guiding principles in this study are the principles gleaned from the reading both the local and international research. These principles are intended firstly to students, teachers, supervisors, curriculum designers, and other stakeholders. Based on the results of the current research, the areas of focus of these principles are strategic instruction, extensive reading, technology-based instruction, the teachers' role, the stakeholders' role, assessment, teacher training, qualified students, integration of skills, and motivating reading texts.

\section{Strategic instruction}

Guiding principle 1: Strategy-based instruction is a must in teaching reading. 
Reading comprehension can be attained by teaching according to a set of strategies per the learners' various needs. Pre-reading strategies, paraphrasing strategies, question-generation strategy, summarizing strategies, and meta-cognitive reading strategies are a few of the strategies addressed in the reviewed international research. On the other hand, the reviewed local research addressed speed reading strategies, electronic mind maps, multiple intelligences, and metacognitive learning strategies. These were all found to positively affect students' reading achievement.

\section{Pedagogical Implications}

The results may have the following pedagogical implications for foreign language teaching:

1. Teachers should model using reading strategies in different contexts.

2. Teachers should encourage students to utilize the strategies they learn.

3. Teachers should identify and replicate the most effective strategies used by fluent readers and train other students to use them.

\section{Extensive reading}

Guiding principle 2: Extensive reading should be effectively enhanced.

Extensive reading can be an effective treatment to improve reading comprehension. A plethora of research suggests improvements in student achievement after extensive reading (e.g., using talking stories books and/or comics).

\section{Pedagogical Implications}

These results may have the following pedagogical implications for foreign language teaching:

1. Teachers should prepare a tight plan for extensive reading according to the students' interests.

2. Teachers should encourage students to read extensively and discuss what they have read in-and outside the school.

\section{Technology-based Instruction}

Guiding principles 3: Technology-based instruction is a must rather than an alternative.

Different types of technology can be utilized in effective reading instruction. Technology use has become rudimentary in education. International and local research addressed different types of technology (e.g., web-based technology, animation techniques, technology-based instruction, MOODLE, electronic mind maps and mobile-assisted language learning) and the effect of blogs and emails on Students' reading achievement.

\section{Pedagogical Implications}

These results may have the following pedagogical implications for foreign language teaching:

1. Teachers must prepare a tight plan to make good use of various technologies.

2. Teachers and students should be trained to utilize technology as an integral part of teaching and learning.

\section{The Teachers' Role}

Guiding principle 4: The teacher should adapt his/her practice to suit the emergent learner requirements. 
Teachers should be trained to use technology to foster their teaching practice in a way that meet their students' needs and interests. Much of the research reviewed discussed the urgent necessity of training teachers to use both technology- and strategy-based reading instruction and to be able to delegate this use to their students.

Pedagogical Implications

These results may have the following pedagogical implications for foreign language teaching:

1. Teacher training, both pre- and in-service, should be made available to teachers who should also be monitored and encouraged to use the innovative techniques and practices put forth by the Ministry of Education.

2. Teachers should be responsible for their professional development and seek to pursue every opportunity towards that end.

\section{The Stakeholders' Role}

Guiding principle 5: Stakeholders should reconsider the schools' infrastructure to graduate learners that can meet the needs of their countries.

Government schools should be fully equipped to facilitate technology integration and multiple modes of technology use by both teachers and students.

Pedagogical Implications

These results may suggest that gradual improvements be made towards better school infrastructure, especially technology-related improvements

\section{Assessment}

Guiding principle 6: Alternative assessment should be tailor-made to fit the learners' needs and progress.

Alternative assessment (e.g., portfolio, self-assessment) may constitute a better recourse than traditional assessment for improving student reading.

\section{Pedagogical Implications}

These results may have the following pedagogical implications for foreign language teaching:

1. Assessment should be a part of teaching and evidence of the student progress rather than summative achievement.

2. Teacher must use different forms of alternative assessments and train students to assess their own progress.

\section{Teacher Training}

Guiding principle 7: Teachers should be qualified and fully-equipped to practice their vocation.

Teachers should be encouraged to keep abreast with up-to-date research in EFL instruction in general and EFL reading in general to apply appropriate strategies and techniques for their own contexts.

\section{Pedagogical Implications}

These results may suggest that teachers be encouraged to conduct research on the obstacles that potentially impede their practice in their respective contexts.

\section{Qualified Students}


Guiding principle 8: Students should be equipped with skills to foster their success within a highly competitive market.

Speed reading is a skill which may foster the students' ability to cope with both tests and real-life reading. Critical and creative reading skills should also be enhanced through strategies (e.g., questioning).

\section{Pedagogical Implications}

These results may have the following pedagogical implications for foreign language teaching:

1. Students should be encouraged to ask and answer questions related to reading texts.

2. Students should be encouraged to engage in timed question/answer tasks.

\section{Motivating Reading Texts}

Guiding principle 9: Reading textbook scripts should be an enjoyable and motivating experience.

Teaching reading, especially for younger learners, should be enjoyable and motivating, decrease their anxiety toward leaning a new language, and foster their reading skill.

\section{Pedagogical Implications}

These results may suggest that reading texts be carefully selected to suit the students with different abilities and backgrounds.

\section{Integration of Skills}

Guiding principle 10: Integration of the skills and language aspects should be effectively applied.

EFL reading instruction will be more effective if it is properly integrated with other skills. The students should utilize the vocabulary, grammatical structures and other aspects that they acquire from reading or listening in other skills such as speaking or writing in authentic situations.

\section{Pedagogical Implications}

These results may suggest that tasks and activities should be planned to integrate skills and foster deep understanding of what they learn in authentic situations.

\section{Recommendations for further research}

In light of the findings of the research, it is recommended that researchers do the following:

- conduct other similar meta-analyses from a wider scope of journals to evaluate the situation in Jordan and the world.

- conduct more meta-analyses on other language skills and aspects.

- conduct more research on reading comprehension of the primary-stage students, as the researchers were only able to locate little existing research (Nasrawi \& Al-Jamal, 2017; Yusuf \& Mohammed, 2013).

- conduct future meta-analyses for qualitative local research. Much local Qualitative research (Bataineh \& Al-Barkat, 2005, 2009, 2011; Bataineh \& Al-Shorman, 2005; Al-Jamal, AlHawamleh \& Al-Jamal, 2013, Qarqez \& Ab Rashid, 2017) may constitute a valuable resource for education in Jordan and elsewhere. 


\section{References}

The format of references is hanging by $(.63 \mathrm{~cm})$

Al-Damiree, R., \& Bataineh, R. (2016). Vocabulary Knowledge and Syntactic Awareness as Potential Catalysts for Reading Comprehension among Young Jordanian EFL Students. Journal of Teaching and Teacher Education, 4 (1), 53-59.

Al-Jamal, D., Al-Hawamleh, M., \& Al-Jamal, G. (2013). An Assessment of Reading Comprehension Practice in Jordan. Jordan Journal of Educational Sciences, 9 (3), 335344. Retrieved 3 March 2019 from https://files.eric.ed.gov/fulltext/EJ1079981.pdf

Al-Khawaldeh, A. (2012). The EFL Reading Comprehension Challenges Faced by Secondary School Students in Jordan. European Journal of Social Sciences, 3, 454-565. Retrieved 23 February 2020 from https://www.academia.edu/attachments/53560523

Al-Makhzoumi, K. (1986). Teaching Reading Comprehension to Secondary Students in Jordan. Dirasat, 3 (6), 76-87

Bataineh, R., \& Al-Barakat, A. (2005). The Reading Interests of Jordanian First-, Second-, and Third-Grade Pupils and the Obstacles Limiting these Interests. Journal of Educational and Psychological Sciences, 6 (3), 107-133

Bataineh, R., \& Al-Barakat, A. (2009). Jordanian Early Primary Stage Teachers' Self-Reported Practices to Develop their Pupils' Reading in Arabic. Mediterranean Journal of Educational Studies, 14 (2), 65-92. Retrieved 20 December 2019 from http://www.um.edu.mt/data/assets/pdf file/006/89853/mjes-1-4-2-no cutlines.pdf

Bataineh, R., \& Al-Barakat, A. (2011). Preservice Childhood Education Teachers' Perception of Instructional Practices for Developing Young Children's Interest in Reading. Journal Research in Childhood Education, 25 (2), 177-193

Bataineh, R., \& Al-Kofeiri, Q. (2018). Morphological Awareness as a Potential Catalyst for Jordanian EFL Students' Reading Comprehension. Lublin Studies in Modern Language and Literature. 42(2), 66-80. Retrieved 12 December 2019 from http://lsmll.journals.umcs.pl 
Bataineh, R., \& Alqatanani, A. (2017). How Effective is Thinking Maps Instruction in Improving Jordanian EFL Learners' Creative Reading Skills? TESOL Journal, https://doi.org/10.1002/tesj.360 1-14

Bataineh, R., \& Al-Shorman, R. (2005). Jordanian EFL University Students' Reading Interests. Abhath Al-Yarmouk (Humanities and Social Sciences Series), 21 (3a), 35-56

Brown, D. (2001). Teaching by Principles: An Interactive Approach to Language Pedagogy. New York: Longman

Eagleton, M., \& Dobler, E. (2007). Reading the Web: Strategies for Internet Inquiry. New York: Guilford

Gersten, R., Baker, S., \& Marks, S. (1998). Teaching English-Language: Guiding Principles and Examples from Research-Based Practice. Oregon: Eugene Research Institute

Grabe, W. (2004). Research on Teaching Reading. Annual Review of Applied Linguistics, 24 (1), 44-69

Hedgcock, J., \& Ferris, D. (2009). Teaching Readers of English. New York: Routledge

Hussien, B. (2012). Analysis of the Real Situation of Teaching Reading Comprehension to First Year Students at the Department of English Language and Literature at Al-Zaytoonah Private University of Jordan. Asian Social Science, 8 (4), 237-251

Jinxiu, J., \& Zhengping, Z. (2016). Principles and Implementation of Reading Activities in Primary School English Class. English Language Teaching, 9 (12), 74-78. Retrieved 20 June 2019 from https://files.eric.ed.gov/fulltext/.pdf

Liu, H., \& Ning, Y. (2017). On the Principles of English Teaching Reform in Higher Vocational Colleges Based on the Basic Requirement of English Curriculum Teaching in Higher Vocational Colleges. English Language Teaching, 10 (9), 11-16. Retrieved 25 July 2019 from https://files.eric.ed.gov/fulltext/EJ1151551.pdf

Mazzante, J., \& Spangler, D. (2015). A research Toolkit of 12 reading strategies for the foreign $\begin{array}{lllllll}\text { language learners. } & \text { Retrieved on } 28 \text { December } 2017 \text { from }\end{array}$ 
https://www.scribd.com/document/283022856/A-Research-Toolkit-of-12-Reading-

$\underline{\text { Strategies-for-the-Second-Language-Class }}$

Mckay, P. (2006). Assessing Young Language Learners. Cambridge: Cambridge University Press

Nasrawi, A., \& Al-Jamal, D. (2017). The Effect of Using Jolly Phonics on Jordanian First Grade Pupils' Reading. International Online Journal of Education and Teaching, 4 (2), 106-119

Omaggio, A. (2001). Teaching Language in Context. Boston: Heinle and Heinle

Qrqez, M., \& Ab Rashid, R. (2017). Reading Comprehension Difficulties among EFL Learners: The Case of First and Second Year Students at Yarmouk University in Jordan. Arab World English Journal, 8 (3), 421-431

Smadi, O., \& Alshara'ah, M. (2015). The Effect of an Instructional Reading Program Based on the Successful Readers' Strategies on Jordanian EFL Eleventh Grade Students' Comprehension. Journal of Education and Practice, 6 (15), 76-87. Retrieved 5 June 2019 from https://files.eric.ed.gov/fulltext/ EJ1079981.pdf

UNESCO International Bureau of Education (2016). Guiding Principles for Learning in the Twenty-First Century. Retrieved 20 December 2017 from http://www.ibe.unesco.org/en/document/guiding-principles-learning-twenty-firstcentury

Wolf, M. (2007). Proust and the Squid: The Story and Science of the Reading Brain. New York: Harper Collins

Yusuf, H., \& Mohammed, S. (2013). Influence of Prior Knowledge Questions on Pupils' Performance in Reading Comprehension in Primary Schools in Kaduna, Nigeria. Advances in Language and Literary Studies, 4 (1), 134-139. Retrieved 1 September 2019 from https://eric.ed.gov/?id=EJ1129732 